\title{
Assessment of Hazardous Impacts of Open Dumping on Water Quality of Nullah Lai Stream Rawalpindi
}

\author{
Hina Imtiaz ${ }^{*}$,Salma Khalid ${ }^{2}$, Kashaf Riaz ${ }^{1}$, Muhammad Arshad Ullah ${ }^{3}$ and Zubair Rehman ${ }^{4}$
}

${ }^{1}$ Department of Environmental Sciences, Fatima Jinnah Women University, Rawalpindi, Pakistan; ${ }^{2}$ Prime Institutes of Public Health, Riphah International University, Islamabad, Pakistan; ${ }^{3}$ National Agriculture Research Centre, Islamabad, Pakistan; ${ }^{4}$ Balochistan Agriculture College, Quetta, Khyber Pakbtunkbwa, Pakistan.

Abstract | The objective of this study is to assess the hazardous impact of open waste dumping on water quality and its subsequent effect on people living in the vicinity of Nullah Lai stream. Water samples were collected from different points of the stream and tested for basic parameters like color, odor and turbidity while EC, $\mathrm{pH}$ and TDS were checked on-site by portable water quality meter. The assessment of heavy metal concentrations i.e. Lead ( $\mathrm{Pb})$, Copper $(\mathrm{Cu})$, Nickel $(\mathrm{Ni})$, Chromium $(\mathrm{Cr})$, Zinc $(\mathrm{Zn})$, Mercury $(\mathrm{Mg})$ and Cadmium $(\mathrm{Cd})$ were carried by Atomic Absorption Spectrophotometer. Significant concentrations of heavy metals were detected except $\mathrm{Cu}, \mathrm{Ni}$ and $\mathrm{Zn}$. Assessment regarding the types of waste generation, diseases among the residents and their opinions about the recycling and proper waste management were carried out through self-administered questionnaires. In order to observe coagulant effect according to Pakistan National Environmental Quality (Standards (Pak-NEQS), the collected samples were treated in the laboratory for identification and recommending suitable coagulant. Three different treatments were practiced i.e. Alum, Lime and Alum+ Lime. For alum, lime and alum + lime the settling time interval was 40, 35 and 20 minutes respectively. Results revealed that the combine treatment (Alum + Lime) effectively reclaimed Total Suspended Solid (TSS) up to $85 \%$, along with $80 \%$ BOD, and $75 \%$ COD. Waste management is core issue that affects the health of people residing in surroundings of Nullah Lai stream. During the question survey it was observed that $70 \%$ respondent reported that they are facing spread of diseases is become major issue. Therefore, the issue needs a special focus in terms of planning and management to save human health and environment.

Received | January 17, 2020; Accepted | June 12, 2020; Published | August 01, 2020

*Correspondence | Hina Imtiaz, Department of Environmental Sciences, Fatima Jinnah Women University, Rawalpindi, Pakistan; Email: hinaimtiaz15@gmail.com

Citation | Imtiaz, H., S. Khalid, K. Riaz, M.A. Ullah and Z. Rehman. 2020. Assessment of hazardous impacts of open dumping on water quality of Nullah Lai stream Rawalpindi. Pakistan Journal of Agricultural Research, 33(3): 570-575.

DOI | http://dx.doi.org/10.17582/journal.pjar/2020/33.3.570.575

Keywords | Environmental impacts, Water quality parameters, Total dissolved solids, Total suspended solids, Questionnaire, Heavy metals

\section{Introduction}

$\mathrm{D}$ umping of solid waste termed as "garbage" that is the unusable and unwanted products in the solid and semi-solid state derived from the human activities and removed by society (Karishnamurti and Naidu, 2003). Like other environmental issues improper management and handling of solid waste is also a burning issue, especially in development countries like Pakistan which not only pose serious threats on the environmental health but is also a risk to the human health. Solid waste comes from various sources like hospitals, public and private institutes, agriculture fields and homes i.e. domestic waste etc. (Ali et al., 2014). The dumping of solid waste will become a major issue if solid waste does not properly managed by concerned authorities causing a chain of environmental impacts like leaching, 
result in contaminations of groundwater, aquifers and depriving air quality etc. (Maleki et al., 2014). Rawalpindi like other cities in the country also does not have any integrated approach for solid waste management. Municipal solid waste is being thrown in the open drains, open spaces and around the street corners and partially burnt in open spaces, which results in aesthetically bad look, outbreak of diseases and environmental pollution (Nisar et al., 2008). At present the services of drainage and sewerage systems of the study area are managed by four organizations: Capital Development Authority (CDA), Water and Sanitation Authority (WASA), Tehsil Municipal Administration (TMA) of Rawalpindi, and Rawalpindi Cantonment Board (RCB), within their administrative jurisdictions. Although there is one operating sewage treatment plant (STP) in CDA, the incoming flow is so low as about $10 \%$ of the total generated sewage in CDA can be treated even partially, and the remaining sewage is discharged into river without any treatment which hamper the flow of water and inundate low-lying areas with devastating effects. Nullah Lai stream also carries a large quantity of wastewater in which approximately $35 \%$ is being collected by RWASA Rawalpindi Water and Sanitation Agency and the remaining 65\% of the wastewater is being disposed of into open drains that ultimately drain off into Nalluh Lai untreated and a partially treated sewage from Islamabad and cantonment area (Haq and Cheema, 2007). This is a major cause of the pollution in the Nullah Lai and its tributaries, followed by the solid waste dumping (Hanif et al., 2020). To overcome this issue production of least unwanted by-products should discouraged through the optimal use of raw materials. As, waste minimization can protect the environment and can improve efficient manufacture economically. These eco-friendly practices are making easier to meet objectives of environmental standards, .and can help endure the environment for forthcoming generations. The main objective of the study is to access the assessment of open of hazardous impacts of open dumping on water quality of Nullah Lai stream and providing treatments to treat the wastewater.

\section{Materials and Methods}

Nullah Lai is natural rainwater faded stream flowing across the Rawalpindi city. The geographical position

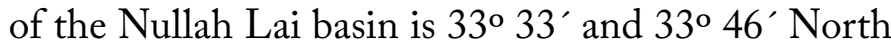
and $72^{\circ} 55^{\prime}$ and $73^{\circ} 07^{\prime}$ East with catchment area of $234.8 \mathrm{Km}^{2}$ (Figure 1). Apart from flow from Islamabad area, 11 main drains of Rawalpindi city also contribute to Nullah Lai (Kamal, 2004).

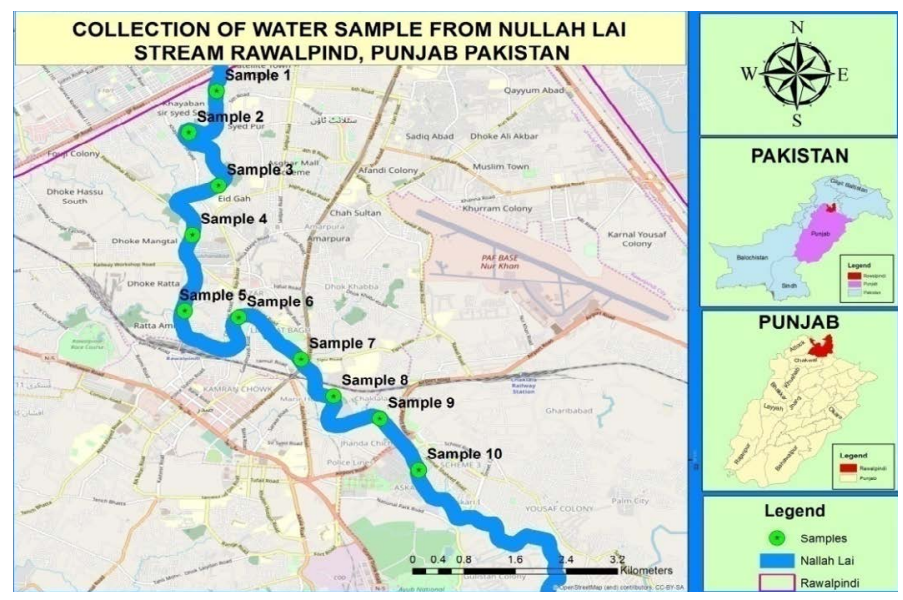

Figure 1: Map showing collection points from Nullah Lai stream.

Ten water samples were collected from different points of the stream and tested for basic parameters such as color, odor, turbidity, whereas EC (Electrical Conductivity), pH, and TDS (Total Dissolved Solid) were tested on the spot using portable water quality meter TSS, BOD and COD of the collected samples were checked in laboratory. Heavy metals in water were analyzed through Electro-thermal Atomic Absorption Spectrophotometer equipped with HGA graphite furnace and mercury hydride system (MHS). Electrical conductivity (EC), dissolved oxygen (DO) and total dissolved solid (TDS) were calculated by electrometric method. Salinity was determined using ion exchange electrode method (Atekwanaa et al., 2004). Biological oxygen demand (BOD) was determined using Azide modification method (5210A) prescribed by American Public Health Association (APHA, 2012).

Solution of $1000 \mathrm{mgL}^{-1} \mathrm{CaO}$ was used for lime treatment. Then, $10 \mathrm{ml}$ of $\mathrm{CaO}$ was added for increasing the dose of lime. Subsequently, sometime sedimentation was observed. Afterward by adding $25 \mathrm{ml}$ lime solution, no change in sedimentation was observed. So, same dose was used for remaining treatment. For alum + lime treatment $1000 \mathrm{mgL}^{-1}$ of aluminum sulfate solution and $1000 \mathrm{mgL}^{-1}$ of $\mathrm{CaO}$ solution were used.

The samples were collected from each sampling point in two clean polythene bottles. One bottle was filled with water and acidified by adding few drops of $5 \% \mathrm{HNO}_{3}$, while the other bottles were filled with 
the water from the same spot having no acid and air bubbles. Water samples were taken into conical flask having $25 \mathrm{ml}$ of nitric acid and $10 \mathrm{ml}$ sample. Nitric acid and water sample were sensibly mixed by trembling conical flask gently. After doing this, $4 \mathrm{ml}$ of per chloric acid and $1 \mathrm{ml}$ of concentrated $\mathrm{H}_{2} \mathrm{SO}_{4}$ were added. The prepared sample was heated for few minutes in digester until the formation of fumes (Soylak and Unsal, 2010). This filtrate was utilized for the evaluation of heavy metals in water by using atomic absorption spectrophotometer (Assubaie, 2015). Heavy metals were analyzed (Clesceri et al., 1998).

Questionnaire survey was carried out in Dhok Charghdin (Civil Lines) and Dhowk Marir Hassan which are most affected areas of Nullah Lai to assess the impact of dumping waste in the stream on the resident. A total of 80 questionnaires were filled by people belonging to different fields.

\section{Results and Discussion}

The physical parameters of the collected water samples such as temperature, color, odor, turbidity, $\mathrm{pH}, \mathrm{EC}$ and TDS were determined through portable water quality meter while the color and odor were determined through vision and smell. The color of the water was yellowish brown and smell was objectionable. In all water samples, the $\mathrm{pH}$ varied from (6.8 to 8.9) with a mean of (7.9) and maximum value of (8.9) in site sample 7 (Table 1). The value of Electrical conductivity varied from (310 to 840 $\left.\mu \mathrm{scm}^{-1}\right)$ with mean of $\left(602 \mu \mathrm{scm}^{-1}\right)$ (Table 2). High conductivity was recorded in different samples due to mixing of the industrial effluents and domestic sewerage waste in the surveyed stream. Further, the occurrence of high level of dissolved salts in water was also observed agreeing the findings of (Abdullah et. al., 2007). Turbidity varied from (35 to 90 NTU) which was found higher than the permissible limit $(<5)$ set by (Pak-EPA, 2008; WHO, 2004). Total dissolved solids (TDS) were recorded within the range of (400$\left.920 \mathrm{mgL}^{-1}\right)$ with mean value of $\left(647 \mathrm{mgL}^{-1}\right)$.

The mean concentrations of $\mathrm{Pb}\left(1.3 \mathrm{mgL}^{-1}\right), \mathrm{Cr}(4.6$ $\left.\mathrm{mgL}^{-1}\right), \mathrm{Hg}\left(0.29 \mathrm{mgL}^{-1}\right)$, and $\mathrm{Cd}\left(0.38 \mathrm{mgL}^{-1}\right)$ were found within hazardous limits (Figure 2) in almost all water samples when assessed using the recommended permissible limits by EPA and WHO (Figure 1 and Table 1).
Table 1: Quality analysis of water samples.

$\begin{array}{llll}\text { Water samples } & \mathbf{p H} & \mathbf{E C}\left(\boldsymbol{\mu s c m}^{-1}\right) & \text { TDS(mgL-1) } \\ 1 & 7.78 & 330 & 450 \\ 2 & 7.9 & 310 & 420 \\ 3 & 7.5 & 480 & 900 \\ 4 & 6.8 & 500 & 400 \\ 5 & 7.5 & 640 & 550 \\ 6 & 7.2 & 760 & 850 \\ 7 & 8.92 & 680 & 640 \\ 8 & 8.45 & 840 & 920 \\ 9 & 8.25 & 780 & 600 \\ 10 & 8.34 & 700 & 740 \\ \text { Mean } & 7.9 & 602 & 647 \\ \text { Std. Error } & 0.2 & 59.2 & 62.5 \\ \text { Minimum } & 6.8 & 310 & 400 \\ \text { Maximum } & 8.9 & 840 & 920 \\ \text { EPA/WHO standards } & 6.5-8.5 & <1000\end{array}$

Carbonates and bicarbonates play their contribution in making the water alkaline. These cause alkalinity in water. By using optimum dose of the alum TSS was decreased from 1421.00 to $570.7 \mathrm{mgL}^{-1}$. BOD was reduced from 215.00 to $135.75 \mathrm{mgL}-1$. COD was reducing from 368.5 to $368.5 \mathrm{mgL}^{-1}$. The lime treatment showed better results as compared to physical treatment as shown in Table 3, but the final readings were above the standard of PakNEQS limits which are 150, 80 and 150 for TSS (Total Suspended Solid), BOD (Biological Oxygen Demand) and COD (Chemical Oxygen Demand) respectively. By adding $20 \mathrm{ml}$ alum solution e and $10 \mathrm{~mL}$ lime solution $\mathrm{CaO}$ increase in sedimentation and flocculation were noticed. The treatment of alum $+\mathrm{CaO}$ was found as a significant combination and has produced incredible results by getting the suspended load below Pak-NEQS. Similarly, BOD and COD were also observed below the Pak NEQS limit. As the coagulants significance of alkalinity is integral part of this treatment like alum needs low alkalinity to initiate the hydrolysis reactions which allow the coagulants to perform accurately and aids in flock formation. Low alkalinity water in addition to supplemental alkalinity is necessary because it will show during this treatment how chemicals will react with wastewater. Parallel analysis for Alum+ Lime treatment shows constructive relation between the alum and lime doses. The doses of alum and lime affect positively with the values of $\mathrm{pH}, \mathrm{EC}$ which ultimately affect the settling time. 
Through questionnaire survey, situational analysis was carried out which revealed that main types of wastes being generated in the areas (Dhok Charghdin and Dhowk Marir Hassan) are compostable (48\%) and recyclable wastes (52\%).In which approximately $(77 \%)$ (including both categories of 100 and 80\%) were being dumped directly into the nearby Nullah Lai because there is no service provision for taking the solid wastes to the landfills and there is no recycling strategy designed for the reuse of solid waste. The stagnant water and the solid waste dumped near the residences affect the health of residents especially the children who are most likely to catch diseases (88\%) (Figure 3). Further, it was observed that most of the houses have small drains in front side of the house while some are situated at the bank of the Nullah Lai. Lack of proper sewerage network, sewage disposal and treatment has worsened the conditions (Figure 3). Study results showed that there is not an adequate service provision in the area for the management of wastes.

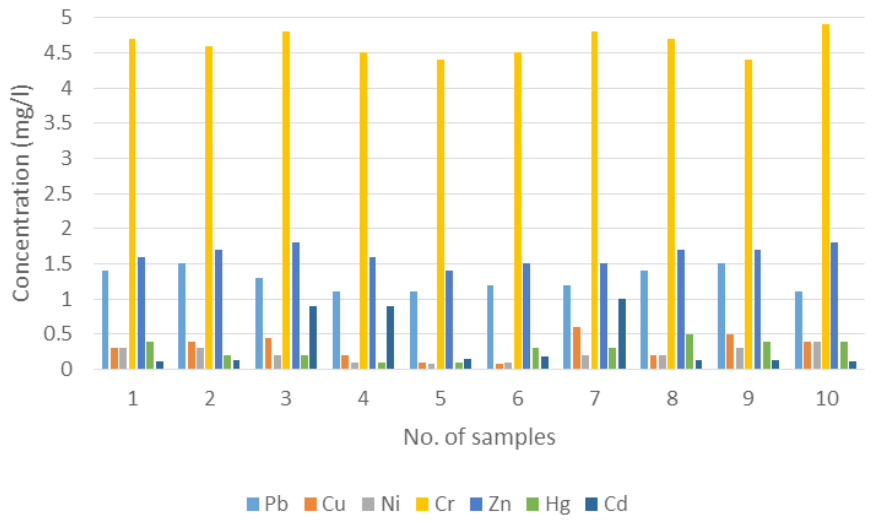

Figure 2: Heavy metals concentration of water samples.

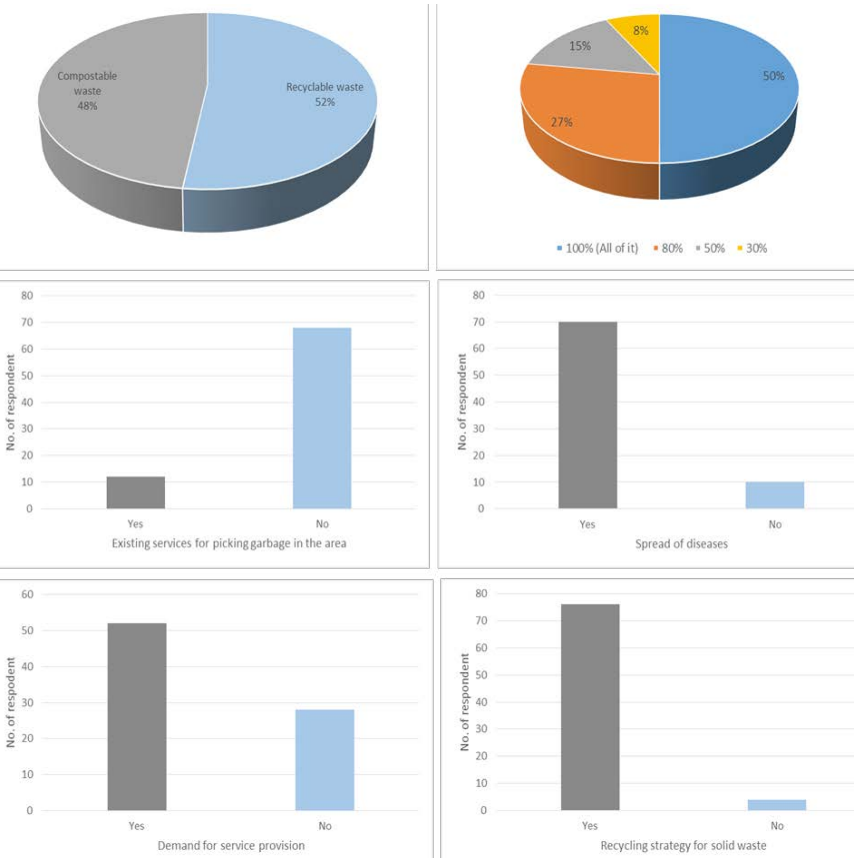

Figure 3: Situational analysis of the study area.
Table 2: Heavy metal concentration with recommended permissible limits.

$\begin{array}{llllll}\begin{array}{l}\text { Param- } \\ \text { eters }\end{array} & \text { Mean } & \begin{array}{l}\text { Std. } \\ \text { error }\end{array} & \begin{array}{l}\text { Mini- }^{-} \\ \text {mum }\end{array} & \begin{array}{l}\text { Maxi- } \\ \text { mum }\end{array} & \begin{array}{l}\text { EPA/WHO } \\ \text { standards }\end{array} \\ \mathrm{Pb} & 1.28 & .05 & 1.10 & 1.50 & \leq 0.05 / 0.01 \\ \mathrm{Cu} & .32 & .06 & .08 & .60 & 2 \\ \mathrm{Ni} & .22 & .03 & .08 & .40 & \leq 0.02 \\ \mathrm{Cr} & 4.63 & .05 & 4.40 & 4.90 & \leq 0.05 \\ \mathrm{Zn} & 1.630 & .042 & 1.40 & 1.80 & 5 / 3 \\ \mathrm{Hg} & .290 & .043 & .10 & .50 & \leq 0.001 \\ \mathrm{Cd} & .38 & .122 & .12 & 1.00 & 0.01 / 0.003\end{array}$

Table 3: Effect of treatments on TSS, BOD and COD parameters $(m g L-1)$.

\begin{tabular}{lllllllllllll}
$\begin{array}{l}\text { Treat- } \\
\text { ments }\end{array}$ & \multicolumn{1}{c}{ Before Treatment } & \multicolumn{2}{l}{ After Treatment } & \multicolumn{3}{l}{ Total Decrease } \\
& TSS & BOD & COD & TSS & BOD & COD & TSS & BOD & COD \\
Physical & 1421 & 215 & 536 & 1170 & 202.75 & 497.5 & 251 & 12.25 & 38.50 \\
Alum & 1421 & 215 & 536 & 570 & 135.75 & 368.5 & 851 & 79.25 & 167.5 \\
Lime & 1421 & 215 & 536 & 586 & 42.25 & 38.50 & 586 & 42.25 & 38.50 \\
Alum+ & 1421 & 215 & 536 & 125 & 72.75 & 87.5 & 586 & 42.25 & 38.50 \\
Lime & & & & & & & & &
\end{tabular}

In fact, garbage and waste disposal in the Lai Nullah is one of the most important environmental concerns. According to the research of Haq and Cheema (2009), waste and garbage disposal in Lai Nullah is mother of all issues; causing floods and water quality health hazards. Tackling this problem is not only the social responsibility of people living around but also city District government presently, operational, technical and financial issues are dominating. Its only $60 \%$ of the generated waste that is being collected and less than $50 \%$ is disposed of in unhygienic way. This not only creates health, unhygienic and environmental problems but is also a major cause of monsoon floods due to blockage of drains and sewers (Ali et al., 2014).

Non-point sources include use of fertilizers and geology of the area and point sources include sewerage water. Death waste organic materials are also the source of nitrate in Lai Nullah. Chemical industries also contribute a lot in discharging nitrate constituents in the water. Therefore, in a conclusion we can say that the major sources of toxic chemical and heavy metals in Lai Nullah are not single sources but coupled with different sources. The major sources include fertilizers, geology of the area, sewerage water, fertilizers, death organic materials and chemical industries (Azizullah et al., 2011). 
Due to the equal neglect of responsible by institutional staff and public concern of where to dump garbage is kept thrown in Lai Nullah without any civic sense and institutional arrangement. The current need of the nearby community of Lai Nullah is the improvement of the existing water quality by responsible authorities to protect them from disastrous health impacts. According to the research study of Nabeela et al. (2014), the only reason behind the water pollution is the lack of the implementation of the environmental laws in the country.

\section{Conclusions and Recommendations}

Wastewater treatment plant should be installed by adding process of coagulation. The combined dose of alum and lime perform better in abstraction of TSS, TDS, BOD, COD .To create awareness among the local people about the importance of proper waste management community needs to be properly educated about waste handling and disposing to the designated sites for from diseases and live in safe and healthy environment.

\section{Author's Contribution}

Hina Imtiaz conceived idea and designed the study, carried out experimental work, sample collection and wrote manuscript. Salma Khalid wrote manuscript and provide her technical input at every step. Kashaf Riaz helped in sample collection and data collection. Muhammad Arshad Ullah did overall management of the article. Zubair Rehman did interpretation of results and proof read the final draft.

\section{Conflict of interest}

The authors have declared no conflict of interest.

\section{References}

Abdullah, M.H., L. Ying, A.Z. Aris and J.H. Park. 2007. Water chemistry in downstream region of Tuaran River: A preliminary assessment on seawater intrusion due to sea level rise. In Park, J.H., Inam, E. and Kim, K.W. (eds). Proc. $1^{\text {st }}$ Int. Workshop Clim. Change Impacts Surface Water Qual. East Asian Watersheds, Chuncheon, Korea. pp. 100-104.

Ali, S.M., A. Pervaiz, B. Afzal, N. Hamid and A. Yasmin. 2014. Open dumping of municipal solid waste and its hazardous impacts on soil and vegetation diversity at waste dumping sites of Islamabad city. J. King Saud Univ. Sci., 26(1): 59-65. https://doi.org/10.1016/j. jksus.2013.08.003

APHA, 2012. Standard methods for the examination of water, $22^{\text {nd }}$ edn. Am. Public Health Assoc., Washington

Assubaie, F.N., 2015. Assessment of the levels of some heavy metals in water in Alahsa Oasis farms, Saudi Arabia, with analysis by atomic absorption spectrophotometry. Arabian J. Chem., 8(2): 240-245. https://doi. org/10.1016/j.arabjc.2011.08.018

Atekwanaa, E.A., E.A. Atekwanaa, R.S. Roweb, D.D. Werkema and F.D. Legalld. 2004. The relationship of total dissolved solids measurements to bulk electrical conductivity in an aquifer contaminated with hydrocarbon. J. Appl. Geophys., 56(4):281-294. https://doi. org/10.1016/S0926-9851(04)00057-6

Azizullah, A., M.N.K. Khattak, P. Richter and D.P. Häder. 2011. Water pollution in Pakistan and its impact on public health, a review. Environ. Int., 37(2): 479-497. https://doi.org/10.1016/j. envint.2010.10.007

Clesceri, L.S., A.E. Greenberg and A.D. Eaton. 1998. Standard methods for the Examination of water and wastewater 20th edition published by Washington D.C., Am. Public Health Assoc. Haq, I.U., and W.A. Cheema. 2007. Adverse effects of poor wastewater management practices on ground water quality in Rawalpindi and mitigation strategies. Rawalpindi: Water and Sanitation Agency (WASA), Rawalpindi District Authority.

Hanif, H., Waseem, A., Kali, S., Qureshi, N. A., Majid, M., Iqbal, M., \& Khan, I. A. 2020. Environmental risk assessment of diclofenac residues in surface waters and wastewater: a hidden global threat to aquatic ecosystem. Environmental Monitoring and Assessment, 192(4), 1-12

Kamal, A., 2004. Pakistan: Lai Nullah Basin flood problem Islamabad Rawalpindi Cities. World Meteorological Organization/Global Water Partnership. Assoc. Prog. Flood Manage., 0112.

Kanwal, S., S. Iram and I. Ahmad. 2012. Wastewater and soil quality assessment of Nullah Lai of Pakistan. Book 55.

Krishnamurti, G.S. and R. Naidu. 2003. 
Solid solution equilibria of cadmium in soils. Geoderma, 113(1): 17-30. https://doi. org/10.1016/S0016-7061(02)00313-0

Maleki, A., H. Amini, S. Nazmara, S. Zandi and A.H. Mahvi. 2014. Spatial distribution of heavy metals in soil, water, and vegetables of farms in Sanandaj, Kurdistan, Iran. J. Environ. Health Sci. Eng., 12(1): 136. https://doi.org/10.1186/ s40201-014-0136-0

Nabeela, F., A. Azizullah, R. Bibi, S. Uzma, W. Murad, S.K. Shakir and D.P. Häder. 2014. Microbial contamination of drinking water in Pakistan, a review. Environ. Sci. Pollut. Res., 21(24): 13929-13942. https://doi. org/10.1007/s11356-014-3348-z

Nisar, H., N. Ejaz, Z. Naushad and Z. Ali. 2008. Impacts of solid waste management in Pakistan: a case study of Rawalpindi city. WIT Trans. Ecol. Environ., 109: 685-691. https://doi. org/10.2495/WM080701

Pak EPA, 2008. National standards for drinking water quality. Pak. Environ. Prot. Agency, Minist. Environ., Islamabad, Pakistan.

Soylak, M. and Y.E. Unsal. 2010. Chromium and iron determinations in food and herbal plant samples by atomic absorption spectrometry after solid phase extraction on single-walled carbon nanotubes (SWCNTs) disk. Food Chem. Toxicol., 48(6): 1511-1515. https://doi. org/10.1016/j.fct.2010.03.017

WHO, 2004. World Health Organization, Guidelines for safe recreational water environments. Coastal and fresh waters (Vol. 1). Geneva: World Health Organization. 